УДК 351

DOI: https://doi.org/10.26642/jen-2019-3(89)-174-177

Л.Л. Колесник, магістрант

Державний університет «Житомирська політехніка»

\title{
Сучасні підходи до розвитку лідерства на державній службі
}

(Представлено Бражевським В.М.)

Статтю присвячено розгляду сучасних підходів щуодо розвитку лідерства на державній службі як одному з орієнтирів для підвищення ефективності державного управління, зокрема розглянуто проблеми співвідношення формального керівництва та лідерства.

Здійснено аналіз основних теорій лідерства та встановлено відсутність єдиного теоретичного підходу до трактування ицього явища. На засадах єдності теорії та практики проаналізовано існуючі сучасні підходи до розвитку лідерства на державній службі та виокремлено деякі з них, які можуть широко використовуватися при нарощуванні та реалізаџї лідерського потениіалу в управлінні на державній службі.

Охарактеризовано основні підходи до вивчення лідерства в сучасному державному управлінні. Доведено необхідність існування та розвитку лідерства на державній службі для їхнього успішного функиіонування.

Формування та розвиток знань щодо сучасних підходів лідерства на державній службі потребують подальшого дослідження та наукового обтрунтування.

Ключові слова: керівник; керівництво; лідер; лідерство; державна служба; державне управління; управління людськими ресурсами.

Лідер - це той, кому вкрай необхідні люди: він спирається не лише на спільну силу у вирішенні завдань, але й на креативність, здатність робити відкриття. Антуан де Сент-Екзюпері

Стати лідером - цее все одно, щзо стати самим собою. Так просто і водночас так складно.

Уорен Бенніс

Актуальність теми. Регулювання суспільних відносин може відбуватися в будь-якій діяльності, в якій основною функцією $є$ держава, яка має специфічний спектр діяльності в державному управлінні. Тому одним із пріоритетів державного управління та роботи на державній службі сьогодні $є$ забезпечення лідерства - розвиток та «вирощування» тих, хто може вести за собою інших задля досягнення чітко сформульованих завдань.

В сучасних умовах велика увага приділяється підбору вищого керівництва органів державної влади та місцевого самоврядування, які мають володіти такими рисами управлінця, як: компетентність, інформованість, відповідальність, здатність і готовність до творчої, інноваційної діяльності.

Сутність проблеми лідерства за проведеними дослідженнями науковців полягає в тому, що при різних ситуаційних змінах в системі може змінюватися їх зміст. В державі наразі триває переломний період, коли змінююся лідери, що призведе до великих змін у державній службі. Це означає зміни змісту феномену лідерства. Тому залишається відкритою проблема сучасних підходів до лідерства на державній службі та набуває актуальності подальших досліджень.

Аналіз останніх досліджень та публікації, на які спирається автор. Дослідженнями підходів до вивчення лідерства має досить широкий спектр зацікавленості, а саме наступними вченими: О.Л. Свенціцький, В.М. М'ясищев, Ф.Ю. Генов, Б.Ф. Ломов, Л.І. Уманський, М.М. Обозов, А.В. Петровський, Г.В. Щокін , Г.М. Андреєва, П.Мучинський, Е.Берн та ін. Різні вчені розглядають лідерство як процес організації групової діяльності, який спрямований на досягнення цілей за короткий термін та з оптимальним ефектом. Відкритою залишається проблема сучасних підходів до лідерства на державній службі та потребує подальших досліджень.

Метою статті $є$ дослідження сучасних підходів до лідерства на державній службі та професійний розвиток сучасного державного службовця.

Викладення основного матеріалу. Лідерство на державній службі в сьогоднішніх умовах набуває особливої уваги, адже саме від ефективного лідера залежить успішна та злагоджена робота цілої команди, iï здатність досягати будь-яких цілей. Основними завданнями розвитку лідерства на державній службі є: становлення та розвиток вищого корпусу державної служби, створення інституціональних передумов для проведення реформи державної служби та державного управління, сталості і наступності функціонування системи державної служби, а також її оперативного реагування на вимоги та виклики, що виникають у зв'язку з процесами суспільної трансформації, економічного розвитку, європейської інтеграції України [1].

() Л.Л. Колесник, 2019 
Сьогодні як приватні, так і державні інституції визначають не лише потребу розвитку лідерського потенціалу, а й свою відповідальність за створення необхідних умов для його розвитку. Кожна країна визначає свій підхід до розвитку спроможності лідерів, але в багатьох країнах створюються спеціальні установи або запроваджуються спеціальні програми навчання керівників, і в першу чергу керівників вищого корпусу.

Реформи, які проводяться в Україні, мають супроводжуватися формуванням високопрофесійної управлінської команди, готової приймати і реалізовувати ефективні рішення як державного, так i регіонального рівня. Сьогодні в Україні не вистачає фахівців зі знаннями і навичками, необхідними для роботи в сучасних умовах. Існує потреба в керівниках нової формації, які вміють швидко та якісно оцінювати ситуацію, самостійно приймати потрібні рішення і мотивувати людей, готові брати на себе відповідальність і розв'язувати поставлені завдання [5, с. 35].

Побудова професійної державної служби та розвиток орієнтованого на результат державного управління вимагають удосконалення підходів, що використовуються для залучення, відбору, навчання і розвитку керівників-лідерів у сфері публічного управління.

Ключовим для керівника-лідера є усвідомлення відповідальності за управління людськими ресурсами. Адже розвиток людських ресурсів залежить від переконаності та рішучості лідерів зміцнити державну службу та від бажання лідерів визнати державних службовців за основний ресурс процесу розвитку та поставитися до них відповідним чином.

Державна посада формально дає керівникові необхідні передумови бути лідером колективу, але автоматично його таким не робить, хоча сам термін «лідер» (від англ. leader) в перекладі і означає «керівник», «провідник», ці поняття тотожними не є. Лідер - ведучий, перший, такий, що йде попереду особа в якій-небудь групі (організації), яка має значний, визнаний авторитет, вплив, який виявляється як дії, що управляють. Член групи, за яким вона визнає право приймати відповідальні рішення в значущих для неї ситуаціях, тобто найавторитетніша особа, яка відіграє центральну роль в організації спільної діяльності й регулювання взаємин у групі, згуртовує навколо себе команду, спроможну досягати поставлених цілей. Різниця між поняттями полягає в тому, що «лідер» висувається завжди «знизу догори», а керівник навпаки, «згори - вниз». 3 поняттям «лідер» тісно пов’язане поняття «лідерство», під яким в загальному розуміють складний механізм взаємодії тих, хто проявляє свою спроможність бути лідером, та тих, на кого цей прояв спрямовано. Для лідерства важливим є не стільки контроль, скільки віра в людей, не покарання за помилки, а навчання на власному досвіді, і відповідно - відкритість до нових ідей, творчість та стратегічність [3, с. 394].

Шлях до ефективної моделі управління державою лежить через кардинальне переосмислення ролі, відповідальності та інструментів діяльності безпосередньо керівників-лідерів - тих, хто вестиме зміни та скеровуватиме інших на досягнення мети. У сьогоднішніх українських реаліях успішна робота залежить не стільки від додержання формальних інструкцій та володіння академічними знаннями, скільки від наявності стратегічного бачення у лідерів, гнучкості у сприянні речей, пошуку розв'язків складних завдань, відкритості до змін та готовності щоденно навчатися, аби завжди «бути на вістрі».

Розглядаючи лідерство, ми маємо на увазі, в першу чергу, психологічні відносини, які виникають в групі, категорію ж «керівництво» розглядають з погляду організації діяльності групи та керування нею.

Сучасні підходи до розвитку лідерства на державній службі можна розділити таким чином:

- заснований на керівнику-лідері;

- заснований на відносинах;

- $\quad$ заснований на підлеглому співробітнику.

Отже, лідером має бути особа, яка створила в межах колективу свій авторитет. Механізм реальної влади має спиратися на заслужений авторитет чи на його повноваження або все разом взяте. Вся влада керівника започаткована на повноваженнях та має передбачати підкорення підлеглих та наявність легітимного примусу. Повноваження, які закріплені за керівником, мають бути документально підтвердженні, при якому визначається місце керівника в ієрархії влади, яке залежать від індивідуальних здібностей.

Наведемо підсумок щодо узагальнень понять керівник та лідер [7, с. 44]:

1) керівник - це індивід, який офіційно має права влади над підлеглими та на якого покладені управлінські функції в державній службі;

2) лідер - це наділений від природи лідерськими якостями індивід, який має безпосередній вплив в групі.

Згідно 3 класифікацією визначень лідерства, запропонованою Р.Стогділлом у праці «Керівництво 3 лідерства», лідерство визначається, у тому числі, й як мистецтво дійти згоди, коли під час управління досягається максимальне співробітництво за мінімальних розбіжностей та вміння переконувати, коли управління здійснюється за допомогою сили переконання та спонукання, мистецтва знання людської природи.

На думку вченого-елітолога Г.Ашина, лідерство - це відносини між людьми в процесі спільної діяльності, в якій одна сторона забезпечує перевагу своєї волі над іншою.

Серед інших визначень лідерство, за В.Шатуном, - це мистецтво впливу на людей, прагнення надихнути їх на те, щоб вони за власним бажанням намагалися досягнути цілей, а управління, як слушно зауважує Герберт А. Саймон, - це знання про те, як маніпулювати іншими людьми та примусити їх зробити те, що вам потрібно [7, с. 22]. 
Як бачимо, однією з ключових категорій загальних визначень лідерства $є$ категорія «мистецтво», що передбачає наявність у носія лідерських якостей, певної психічної енергії.

Природа лідерства як такого досить складна й не піддається однозначній інтерпретації. Важливе місце в розумінні природи феномена лідерства займає психологічна інтерпретація лідерства, в основі якої лежить концепція психоаналізу Зигмунда Фрейда, який вважав, що в основі лідерства $\epsilon$ саме пригнічене лібідо. У процесі сублімації пригнічене лібідо проявляється в людині в прагненні до створення і, в тому числі, до лідерства. У багатьох людей володіння керівними позиціями виконує суб'єктивно-компенсаторні функції, дає можливість подавляти або переборювати різноманітні комплекси, почуття неповноцінності тощо. Треба зауважити, що послідовники Фрейда трактують лібідо більш широко - як психічну енергію взагалі.

Надзвичайно цікавою для розуміння природи лідерства $є$ концепція, запропонована російським вченим-етнологом Л.Гумільовим. Імпульсом до лідерства $є$ пасіонарність - особливий вид енергії, особлива пристрасть, притаманна лише окремим людям і спрямована на перетворення навколишнього світу. На думку вченого, Наполеон, Олександр Македонський та інші історичні особистості - приклади пасіонаріїв, які зуміли поламати інерцію традиції і дали пасіонарний імпульс для історичного злету своїх народів $[4$, с. 105$]$.

Наразі досить часто зустрічається проблема наявності висококваліфікованих, компетентних $\mathrm{i}$ професійних державних службовців-лідерів. Державній службі необхідні працівники, які володіють лідерськими якостями і навичками. Адже успішними державними службовцями, які були б готові до виконання будь-яких завдань та розв'язання проблем, що виникають перед ними, не можуть взятися нізвідки. Як показує досвід інших провідних країн, успішні державні службовці проходять навчання, які розвивають та отримують через консультативну підтримку. Рекомендації щодо сучасних підходів до лідерства мають вдосконалюватися на практиці до того, поки не буде досягнений певний рівень компетенцій [8, с. 256].

Пріоритетні пропозиції удосконалення сучасних підходів до лідерства на державній службі мають містити такі складові:

1. Освітня, яка регламентована процедурами, які спрямовані на зміну форм навчання в межах застосування сучасних підходів до лідерства на державній службі з метою підготовки ії до практичної управлінської діяльності;

2. Індивідуальна, яка включає існування особистості та забезпечує персональність його готовності до змін та ресурси впливу;

3. Групова взаємодія має базуватися на проведеному аналізі поведінки лідерів в межах виконання своїх управлінських обов'язків та підтримки ділових відносин в державній службі;

4. Організаційна займається певним перезавантаженням діяльності державної служби, яка спрямована на активність їх у формуючу діяльність щодо підвищення якості державного управління.

Таким чином, можемо констатувати, що домінуючим критерієм вираження суті феномена лідера $\epsilon$ прагнення до влади.

В сучасному світі категорія «лідерство» має більш ширшу інтерпретацію та нові підходи до його визначення. За визначенням Головного управління державної служби України було визначено та розроблено профілі компетенції лідерства для певних категорій керівництва на державній службі. Лідерство $€$ на сьогодні новітньою концепцією в управлінні, які застосовуються в управлінні змінами, для якого головним $€$ не рівень посади, а можливість впливу на діяльність особи.

Висновки та перспективи подальших досліджень. Розглянувши сучасні підходи лідерства на державній службі, як одного з процесів організації управління малою соціальною групою, який сприяє досягненню групових цілей в оптимальні терміни та з оптимальним ефектом, можна сказати наступне, що лідерство нерозривно пов'язане зі стилем керівництва, яке проявляється в управлінні та його умінні працювати в команді. Лідерство на державній службі - це один з процесів організації управління малою соціальною групою, який сприяє досягненню групових цілей в оптимальні терміни та 3 оптимальним ефектом, рушійною силою якого $є$ авторитет керівника-лідера. Якщо в чистому вигляді діяльність керівника, насамперед, зорієнтована на виконання групою завдання, а діяльність лідера - на відносини в групі, то відповідно керівнику-лідеру мають бути притаманні всі загальні якості як лідера (неформальний авторитет, інтелектуальні здібності, здатність до прийняття ризикових рішень, спроможність до витримки в стані непевності, нахил до панування над іншими людьми, інтелігентність, наполегливість, уміння передбачати, переконувати, прагнення до успіху, комунікативність тощо), так і керівника (формальний авторитет, аналітичні здібності, професійні знання, висока загальна культура, розуміння меж законодавства, постійне прагнення до отримання нових знань).

Однозначно, владні позиції керівника зміцнюються, якщо він, окрім формальних підстав керувати, отримає й визнання своїх підлеглих як лідер завдяки особистим якостям: стосунки «лідер-послідовник», $\epsilon$ набагато тіснішими і результативнішими, ніж відносини «начальник-підлеглий». 
Отже, в нашому випадку необхідно усвідомлювати, що коли в керівника немає вроджених чи набутих у процесі довготривалої соціалізації задатків до лідерства, відчуття та розуміння високої власної відповідальності за людей, що перебувають у підпорядкуванні, та доручену справу, то, можливо, спеціальним курсом навчання їх можна буде розвинути до певного рівня, однак яка б не була якість такого лідерства, вона не може бути високою «а priori».

I навпаки, якщо у керівника присутні вродженні лідерські якості, то спеціальне навчання може розвинути їх та вивести на новий якісний рівень.

Таким чином, кожний із зазначених сучасних підходів до розвитку лідерства на державній службі має право на існування, оскільки ці теорії лідерства мають вірогідність та оптимальний теоретичний підхід, при якому залежність від щоденної професійної ситуації та базуються на керівництві лідера. Проаналізовані сучасні підходи до розвитку лідерства досить успішно можуть впроваджуватись у середовищі для удосконалення якості менеджменту в органах влади, які в свою чергу мають підвищувати якість державних послуг та ефективність діяльності державних службовців.

Відповідно існує необхідність створення системи відбору та рекрутування на керівні посади в органах державної службі тих кандидатів, які володіють сильними лідерськими якостями, та подальшого розвитку системи культивування лідерства на державній службі як однієї 3 необхідних умов для розвитку професійної державної служби в Україні.

\section{Список використаної літератури:}

1. Вивчення потреб у навчанні вищого корпусу державної служби (дослідження проведене у 2011 році) / Проект «Реформа управління персоналом на державній службі в Україні» // Школа вищого корпусу державної служби. - 2013.

2. Вишневський A.B. Застосування моделі та профілів компетентності для управління персоналом в системі державної служби / А.В. Вишневський, О.С. Хмельницька // Вісник державної служби України. - 2014. - № 4. - C. $38-44$.

3. Гайдученко С.О. Фактори розвитку технології оцінювання в управлінні персоналом державної служби / С.O. Гайдученко // Теорія та практика державного управління. - Х. : Магістр, 2013. - № 1. - С. 393-398.

4. Головатий М.Ф. Політична психологія : підручник для вищих навчальних закладів. / М.Ф. Головатий. - К. : МАУП, 2016. - $397 \mathrm{c}$

5. Гончарук H.T. Оцінювання керівного персоналу державної служби України / Н.T. Гончарук //Вісник державної служби України. - 2017. - № 3. - С. 34-38.

6. Драган I.O. Менеджмент в системі органів державної влади та місцевого самоврядування : навч. посібник / О.М. Кондрашов, О.І. Дацій, І.О. Драган та ін. - К. : ТОВ «ДКС центр», 2013. - 366 с.

7. Логунова М.М. Соціально-психологічні аспекти управлінської діяльності / М.М. Логунова. - К. : Центр сприяння інституціонального розвитку державної служби, 2016. - 196 с.

8. Пашко Л.А. Управлінське лідерство як запорука ефективності функціонування сфери державного управління / Л.А. Пашко // Адміністративна реформа в Україні: сучасний стан, проблеми та перспективи : монографія / за заг. ред. Н.Р. Нижник, Н.Т. Гончарук. - Д. : Моноліт, 2017. - С. 255-271.

9. Указ Президента України «Про Президентський кадровий резерв «Нова еліта нації» № 246/2012 від 5 квітня 2012 року [Електронний ресурс]. - Режим доступу : http:// www. president. gov. ua/documents/14656.html.

\section{References:}

1. «Vyvchennja potreb u navchanni vyshhogo korpusu derzhavnoi' sluzhby (doslidzhennja provedene u 2011 roci)» (2013), Proekt «Reforma upravlinnja personalom na derzhavnij sluzhbi v Ukrai'ni», Shkola vyshhogo korpusu derzhavnoi' sluzhby.

2. Vyshnevs'kyj, A.V. and Hmel'nyc'ka, O.S. (2014), «Zastosuvannja modeli ta profiliv kompetentnosti dlja upravlinnja personalom v systemi derzhavnoi' sluzhby», Visnyk derzhavnoi' sluzhby Ukrai'ny, No. 4, pp. 38-44.

3. Gaiduchenko, S.O. (2013), «Factors in the development of evaluation technology in the management of civil service personnel», Theory and practice of public administration, View of Har RI NAPA «Magister», H., No. 1. pp. 393 398.

4. Golovatyj, M.F. (2016), Politychna psyhologija, pidruchnyk dlja vyshhyh navchal'nyh zakladiv, MAUP, K., 397 p.

5. Goncharuk, N.T. (2017), «Ocinjuvannja kerivnogo personalu derzhavnoi' sluzhby Ukrai'ny», Visnyk derzhavnoi' sluzhby Ukrai'ny, No. 3, pp. 34-38.

6. Dragan, I.O., Kondrashov, O.M. and Datsiy, O.I. and others (2013), Menedzhment v systemi organiv derzhavnoi' vlady ta miscevogo samovrjaduvannja, navch. posibnyk, LLC «DKS Center», K., 366 p.

7. Logunova, M.M. (2016), Social'no-psyhologichni aspekty upravlins'koi' dijal'nosti, Centr spryjannja instytucional'nogo rozvytku derzhavnoi' sluzhby, K., 196 p.

8. Pashko, L.A. (2017), «Upravlins'ke liderstvo jak zaporuka efektyvnosti funkcionuvannja sfery derzhavnogo upravlinnja», Administratyvna reforma v Ukrai'ni: suchasnyj stan, problemy ta perspektyvy, monografija, in Nyzhnyk, N.R., Goncharuk, N.T. ed., Monolit, D., pp. 255-271.

9. Administracija Prezydenta Ukrai'ny (2012), «Pro Prezydents'kyj kadrovyj rezerv «Nova elita nacii'», Ukaz, No. 246/2012, [Online], available at: http:// www. president. gov. ua/documents/14656.html

Колесник Любов Леонідівна - магістрант I курсу ЗДУм-18-9 ФПУП Державного університету «Житомирська політехніка».

Наукові інтереси:

- сучасні підходи до лідерства на державній службі. 